\title{
The Effect of Ketogenic Diet on Bcl-2 Expression as An Apoptosis Marker in Cancer Treatment: A Systematic Review
}

\author{
Vania Islamey Kusuma1 ${ }^{1}$, Reny I'tishom² ${ }^{\mathbb{D}}$, Ema Qurnianingsih ${ }^{3} \mathbb{D}$, Purwo Sri Rejeki ${ }^{4 *}$ (D)
}

${ }^{1}$ Faculty of Medicine, Universitas Airlangga, Surabaya, Indonesia

${ }^{2}$ Department of Biology Medicine, Faculty of Medicine, Universitas Airlangga, Surabaya, Indonesia

${ }^{3}$ Department of Biochemistry, Faculty of Medicine, Universitas Airlangga, Surabaya, Indonesia

${ }^{4}$ Department of Physiology, Faculty of Medicine, Universitas Airlangga, Surabaya, Indonesia

\section{A R T I C L E I N F O}

\section{Article history:}

Received 23 August 2021

Received in revised form 10

September 2021

Accepted 19 October 2021

Available online 30 October 2021

\section{Keywords:}

Ketogenic Diet,

Cancer,

Bcl-2,

Apoptosis.

\section{*) Corresponding author:}

purwo-s-r@fk.unair.ac.id

\begin{abstract}
A B S T RA C T
Introduction: Ketogenic diet seems to be in a great demand nowadays as a lot of people are interested in adopting it into their lifestyle. It is also found that the ketogenic diet shows several beneficial effects including cancer prevention. However, the detail mechanism still remains unknown. Therefore, this review was aimed to find out the effect of ketogenic diet on Bcl-2 (B-cell lymphoma-2) expression in cancer.

Methods: We searched published literatures in PubMed through 2011-2020 using specific keywords. The literatures were filtered according to inclusion and exclusion criteria. Animal model, total sample size, underlying condition/inflammatory process occurs, details of the intervention/diet including diet contents in control group and high-fat group, and the duration of the intervention, Bcl-2 results, and p-value were extracted.

Results: 7 studies were included in this review. Bcl-2 expression found decrease in 5 out of 6 studies. Similar result also obtained in Bcl-2 protein level, which measured by western blot. Bcl2 protein level shows a decrease in 2 out of 3 studies.

Conclusion: This review shows that high-fat diet that contained in ketogenic diet most likely lead to decrease in Bcl-2 expression. Therefore, indicating the ability of ketogenic diet to affect cancer progression by inducing apoptosis process.
\end{abstract}

\section{Introduction}

Nowadays, lots of people are interested in consuming ketogenic diet because it helps in losing weight. Besides weight loss, ketogenic diet was developed to control blood sugar level, reduce serum triglycerides, treat cancer, alzheimer, and epilepsy. ${ }^{1}$ Ketogenic diet contains of high fat with low carbohydrate and adequate protein to trigger our body to digest fat more than carbohydrate. This high-fat diet aims to activate ketogenesis to break down the fat into fatty acids and ketone bodies. Then, ketone bodies cross the blood-brain barrier to provide energy for our brain. ${ }^{2}$

According to data from World Health Organization (WHO) in 2019, cancer is the second leading cause of death in the world in which 1 out of 6 deaths is caused by cancer. It has been reported that an increase in number of new cases until 18.1 million, and number of deaths until 9.6 million in 2018 in worldwide. While in Indonesia, there were 348.809 new cases and 207.210 deaths in 2018. ${ }^{3,4}$ There are lots of factors that can increase the risk of cancer, such as age, alcohol, chronic inflammation, obesity, radiation, immunosuppressant, infectious agent and etc. ${ }^{5}$ Some preventions can be done, by reducing carcinogenic exposure and do healthy diet in order to maintain our body weight. It is said that ketogenic diet can help to prevent cancer, but the detail mechanism is still unknown yet. $^{6}$

Bcl-2 is a family protein which gene is located in chromosome 18 , its role is to control a cell survival by blocking apoptosis. In normal cells, unmutated loci of p53 will be activated, and this activation leads to transcription of Bcl2 Associated X protein (Bax). Bax expression will increase and cause translocation into mitochondria outer membrane. Translocation of Bax causes matrix swelling and cytochrome-c release. Release of cytochrome-c activates caspase pathway then resulting in apoptosis. However, Bcl-2 acts as Bax 
inhibitor and can also impede the cytochrome-c release. ${ }^{7}$ In malignancy, some loci in p53 is mutated and Bcl-2 gene is transferred to different chromosome, which explains why Bcl2 is found in large amount and how cancer cells can survive from dying. $8 \mathrm{Bcl}-2$ expression increases by avoiding apoptosis which helps oncogenic transformation, so that will explain the unstoppable growth of tumor, and resistance to therapy. ${ }^{9}$

Administration of ketogenic diet results in ketone bodies and is expected to be used by normal cells as primary energy source due to lack of glucose. Meanwhile, in cancer cells cannot metabolize ketone bodies because of mitochondrial dysfunction. In ketosis state, normal cells are expected to adapt to metabolize ketone bodies while cancer cells will starve of energy. ${ }^{10}$

This review was conducted to determine the effect of ketogenic diet on the expression of Bcl-2 as suppressor of cancer cell growth. By the end of this review, Bcl-2 expression was extracted as an apoptosis marker of cancer.

\section{Methods}

This review searched all relevant literatures in PubMed database through January 2011 until May 2020 using keywords ((()(ketogenic diet) OR highfat diet) OR diet-induced obesity) AND (((cancer) OR neoplasm) OR tumor)) AND bcl-2). Only free full access articles and English-written literatures were included. 18 literatures that did not use highfat diet as the experimental treatment or did not show the result of Bcl-2 independently were excluded. Then from all 7 selected studies according to inclusion and exclusion criteria, we extracted data related first author, published year, animal model, total sample size, underlying condition/inflammatory process occurs, details of the intervention/diet including diet contents in control group and high-fat group, and the duration of the intervention, $\mathrm{Bcl}-2$ results, and p-value.

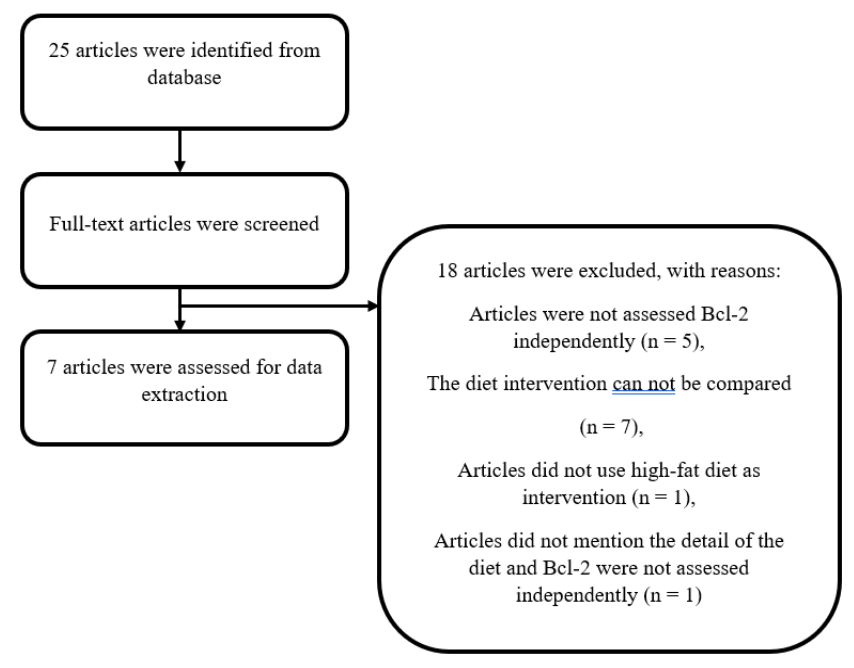

Figure 1. Flow chart of study selection

Table 1. Summary of included studies in the review

\begin{tabular}{|c|c|c|c|c|c|c|c|c|}
\hline \multirow[b]{2}{*}{ Author } & \multirow{2}{*}{$\begin{array}{c}\text { Animal } \\
\text { Model, } \\
\text { Sample Size }\end{array}$} & \multirow[b]{2}{*}{$\begin{array}{l}\text { Underlying } \\
\text { Condition }\end{array}$} & \multicolumn{2}{|r|}{ Diet } & \multicolumn{3}{|c|}{ Bcl-2 } & \multirow[b]{2}{*}{ p-value } \\
\hline & & & Control & High Fat & $\begin{array}{c}\text { duration } \\
\text { (weeks) }\end{array}$ & control & $\begin{array}{c}\text { high - } \\
\text { fat }\end{array}$ & \\
\hline $\begin{array}{l}\text { Sakr et } \\
\text { al., } 2019\end{array}$ & $\begin{array}{l}\text { Male } \\
\text { Sprague-- } \\
\text { Dawley rats, }\end{array}$ & $\begin{array}{l}\text { Metabolic } \\
\text { dysfunction }\end{array}$ & $\begin{array}{l}\text { Standard } \\
\text { laboratory } \\
\text { chow diet }\end{array}$ & $\begin{array}{l}10.1 \% \text { fat }(5 \% \text { co- } \\
\text { conut oil and } 5.1 \% \\
\text { linoleic acid), } 17 \% \\
\text { protein, } 51.6 \% \text { car- } \\
\text { bohydrate, and } 4 \% \\
\text { cholesterol with } 0.5 \\
-1 \% \text { cholic acid }\end{array}$ & 15 & HFD $<$ & Control & $\mathrm{p}<0.05$ \\
\hline $\begin{array}{l}\text { Liu et al., } \\
2019\end{array}$ & $\begin{array}{l}\text { Male } \\
\text { C57BL/6 mice } \\
\mathrm{n}=20\end{array}$ & $\begin{array}{l}\text { Metabolic } \\
\text { syndrome }\end{array}$ & $\begin{array}{l}10 \% \text { fat, } \\
70 \% \\
\text { carbohy- } \\
\text { drate, } 20 \% \\
\text { protein }\end{array}$ & $\begin{array}{l}60 \% \text { fat, } 20 \% \\
\text { carbohydrate, } 20 \% \\
\text { protein }\end{array}$ & 6 & HFD $<$ & Control & $\mathrm{p}<0.01$ \\
\hline
\end{tabular}




\begin{tabular}{|c|c|c|c|c|c|c|c|}
\hline $\begin{array}{l}\text { Sahraoui } \\
\text { et al., } \\
2016\end{array}$ & $\begin{array}{l}\begin{array}{l}\text { Psamommys } \\
\text { obesus rats }\end{array} \\
\mathrm{n}=20\end{array}$ & $\begin{array}{l}\text { Myocardial } \\
\text { anomalies }\end{array}$ & $\begin{array}{l}\text { normal } \\
\text { diet of } 50 \\
\text { g natural } \\
\text { halophil- } \\
\text { ic plants } \\
\text { (Sal- } \\
\text { icornia; } \\
\text { composi- } \\
\text { tion of the } \\
\text { halophilic } \\
\text { plants: } \\
\text { water } 80.8 \\
\text { g; mineral } \\
\text { salts } 6.9 \text { g; } \\
\text { lipids } 0.4 \\
\text { g; proteins } \\
3 \text { g; carbo- } \\
\text { hydrates } \\
8.4 \text { g; and } \\
45-50 \\
\text { kcal/100 } \\
\text { g) }\end{array}$ & $\begin{array}{l}\text { halophilic plants } \\
(50 \mathrm{~g} \text { ) plus the } \\
\text { daily addition of } \\
\text { one-quarter (5 } \\
\text { g) of cooked egg } \\
\text { yolk (composition } \\
\text { of the cooked egg } \\
\text { yolk: water } 40-46 \\
\text { g; proteins } 13.5- \\
17.5 \mathrm{~g} \text {; carbohy- } \\
\text { drates } 0.2 \mathrm{~g} \text {; lipids } \\
30-31 \mathrm{~g} \text {; choles- } \\
\text { terol } 1.2-1.3 \mathrm{~g} \text {; } \\
\text { and } 370-400 \mathrm{kcal} / \\
100 \mathrm{~g} \text { ) }\end{array}$ & 16 & $\begin{array}{ll}1.00 \pm & 0.84 \pm \\
0.12 & 0.11\end{array}$ & $\mathrm{p}=0.3387$ \\
\hline $\begin{array}{l}\text { Hill et } \\
\text { al., } 2015\end{array}$ & $\begin{array}{l}\text { male } \\
\text { C57BL/6 } \\
\text { mice } \\
\mathrm{n}=13\end{array}$ & Obesity & $10 \%$ fat & $60 \%$ fat & 9 & $\begin{array}{l}\text { HFD }<\text { Control } \\
\text { HFD }>\text { Control } \\
\text { in protein lev- } \\
\text { el (by western } \\
\text { blot) }\end{array}$ & $\mathrm{p}<0.01$ \\
\hline $\begin{array}{l}\text { Zhang et } \\
\text { al., } 2015\end{array}$ & $\begin{array}{l}\text { male } \\
\text { ApoE-/- } \\
\text { mice } \\
\mathrm{n}=10\end{array}$ & $\begin{array}{l}\text { Atheroscle- } \\
\text { rosis }\end{array}$ & $\begin{array}{l}\text { normal } \\
\text { diet (de- } \\
\text { tails not } \\
\text { men- } \\
\text { tioned) }\end{array}$ & $\begin{array}{l}\text { high-fat diet } \\
\text { (details not men- } \\
\text { tioned) }\end{array}$ & 12 & $\begin{array}{l}\text { no significant } \\
\text { change } \\
\text { HFD }<\text { Control } \\
\text { in protein lev- } \\
\text { el (by western } \\
\text { blot) }\end{array}$ & $\mathrm{p}<0.05$ \\
\hline $\begin{array}{l}\text { Gong et } \\
\text { al., } 2012\end{array}$ & $\begin{array}{l}\text { male } \\
\text { ApoE-/- } \\
\text { mice } \\
\mathrm{n}=29\end{array}$ & $\begin{array}{l}\text { Atheroscle- } \\
\text { rosis }\end{array}$ & $\begin{array}{l}\text { normal } \\
\text { diet (de- } \\
\text { tails not } \\
\text { men- } \\
\text { tioned) }\end{array}$ & $\begin{array}{l}\text { high-fat diet } \\
\text { (details not men- } \\
\text { tioned) }\end{array}$ & 12 & $\begin{array}{l}\text { no significant } \\
\text { change }\end{array}$ & $\mathrm{p}<0.05$ \\
\hline $\begin{array}{l}\text { Aguiar e } \\
\text { Silva et } \\
\text { al., } 2012\end{array}$ & $\begin{array}{l}\text { male Wistar } \\
\text { rats } \\
\mathrm{n}=40\end{array}$ & $\begin{array}{l}\text { Hepatocel- } \\
\text { lular Carci- } \\
\text { noma }\end{array}$ & $\begin{array}{l}6 \% \text { fat, } \\
51 \% \text { car- } \\
\text { bohydrate } \\
26 \% \text { pro- } \\
\text { tein, and } \\
3.64 \mathrm{kcal} / \mathrm{g} \\
\text { with calo- } \\
\text { ries from } \\
\text { saturated } \\
\text { fat }(2.5 \%) \\
\text { and unsat- } \\
\text { urated fat } \\
(9.5 \%)\end{array}$ & $\begin{array}{l}21 \% \text { fat; } 42 \% \\
\text { carbohydrate, } 24 \% \\
\text { protein and } 4.54 \\
\mathrm{kcal} \cdot \mathrm{g}-1 \text { with } \\
\text { calories from sat- } \\
\text { urated fat }(9.95 \%) \\
\text { and unsaturated } \\
\text { fat }(39.1 \%)\end{array}$ & 16 & $\begin{array}{l}\text { HFD }<\text { Control } \\
\text { in protein lev- } \\
\text { el (by western } \\
\text { blot) }\end{array}$ & $<0.05<p<0.001$ \\
\hline
\end{tabular}




\section{Results}

25 identified articles from PubMed were assessed in full-text. 18 articles were excluded based on exclusion criteria, and 7 studies were selected. All selected studies used high-fat diet as experimental intervention and examined Bcl-2 expression independently. (Table 1)

According to Sakr et al. (2019), high-fat diet promoted inflammatory process. However, there was a significant decrease in Bcl-2 expression in highfat diet group compared to control group $(\mathrm{p}<0.05)$, which means there was an increase in apoptosis as well as the expression of Bax. ${ }^{11}$ This result is similar with a research which was conducted by Liu et al. (2019), a significant decrease in Bcl-2 was also found. In contrast, this is supported by an increase in Bax and Caspase-3 expression. ${ }^{12}$ Sahraoui et al. (2016) reported that in animal model of myocardial anomalies, high-fat diet result in a decrease of Bcl-2 expression. This result is in line with an increase of $\mathrm{Bax} / \mathrm{Bcl}-2$ ratio, implying an occurrence of apoptosis process. ${ }^{13}$ As reported by Hill et al. (2015), Bcl-2 gene expression was found slightly lower in high-fat diet group $(p<0.01)$. While in contrary, $\mathrm{Bcl}-2$ protein level was elevated in high-fat group $(p<0.001) .{ }^{14}$ However, this result is the opposite of Zhang et al. (2015), which showed that there was no significant change in Bcl-2 gene expression, but it was found a decrease in Bcl-2 protein levels $(p<0.05) .{ }^{15}$ Based on findings from Gong et al. (2012), it was found significant decrease of Bcl-2 gene expression, examined through immunohistochemistry and confirmed by examination of $\mathrm{Bcl}-2$ protein level through western blotting $(\mathrm{p}<0.01) .{ }^{16}$ Research conducted by Aguiar e Silva et al. (2012) revealed that a decrease in $\mathrm{Bcl}-2$ protein level in high-fat diet group $(<0.05<\mathrm{p}<0.001)$, which was examined by western blotting. ${ }^{17}$

\section{Discussion}

In this review, 7 articles were selected to be included. Bcl-2 result from control group, which are treated using normal diet, and group of high-fat diet intervention that is also contained in ketogenic diet, were extracted to compare the result. As reported in the result, mice/rats which were treated with high-fat diet mostly shows a decrease number of Bcl-2 either in gene expression or protein level. To conclude, it is indicated that high-fat diet will reduce Bcl- 2 expression.

In accordance with a research that was conducted by de Oliveira Andrade et al. (2014) in breast cancer model, high-fat diet can reduce $\mathrm{Bcl}-2 / \mathrm{Bax}$ ratio. This result is in line with the theory that to reduce tumorigenesis, Bcl-2 as an anti-apoptotic protein need to be reduced, while Bax as a pro-apoptotic protein is supposed to be increased, and for these as a ratio, it should show a decrease. ${ }^{18}$ This result indicates that high-fat diet promotes cell apoptosis. However, based on a research by Dogan et al. (2007), it was exhibited that high-fat diet did not change Bcl-2 significantly. Nonetheless, Bcl-xL (B-cell lymphoma-extra large), another anti-apoptotic protein from Bcl-2 family protein, was found lower significantly, compared to the low-fat diet administration. ${ }^{19}$

Some of these selected studies mentioned that reduction of Bcl-2 expression is associated with hypercholesterolemia, due to antioxidant properties of Bcl-2. Administration of high-fat diet results in excessive of fatty acid, and cause increase in oxidative stress, thus will lead to injury and activation of inflammatory process. Apoptosis is known to be occurred when there is inflammatory process. Therefore, the result of Bcl-2 expression was low. ${ }^{11,13}$ Hill et al. (2015) stated that the mechanism of cell survival and apoptosis is regulated by Nuclear Factor (NF)-KB-dependent. NF-kB will activate $\mathrm{Bcl}-2$ and $\mathrm{Bcl}-\mathrm{xL}$ as pro-survival regulators, leads to inhibition of autophagosome, for example Beclin-1. Inhibition of autophagosome causes p62 accumulation, and results in cell survival.14 However, Zhang et al. (2015) reported that high-fat diet resulted in increasing level of micro RNA (miR)-429. This miR-429 will suppress Bcl-2 mRNA translation by 3'-UTR binding leading to decrease in Bcl-2 protein level but no change in Bcl-2 mRNA.15

Another possible mechanism of how ketogenic diet or high-fat diet alter Bcl-2 is through Phosphatidylinositol 3-Kinase (PI3K) /Akt signaling. A research conducted by Wu et al. (2016), reported that high-fat diet downregulates Akt signaling. It is exhibited that high-fat diet results in significant decrease of Akt protein level. By this, as Akt is expressed in low level, downstream effects of it, including Bcl-2, will be inhibited. ${ }^{20}$ These inhibitions allow cell to proceed apoptosis. According to Gottlieb et al. (2002), Akt altered Bcl-2 expression via Mdm2 (Murine Double Minute-2) by phosphorylating Serine166. Translocation of $\mathrm{Mdm} 2$ to nucleus leads to p53 inactivation, whereas active p53 can suppress Bcl-2 transcription. In ketogenic diet, Akt will be inhibited and thus, Mdm2 will not be translocated from cytoplasm. As in Mdm2 stays in cytoplasm, p53 will be activated and results in decreasing transcription of Bcl-2. ${ }^{21}$ In line with a research that was conducted by Harahap, Irfannuddin and Murti (2018), ketogenic diet can increase apoptosis process. It is proven that expression of caspase-3 was elevated. Therefore, by this elevation of caspase-3 expression, apoptosis process in mitochondria was occurred, and Bcl-2 expression as an anti-apoptosis protein was supposed to be lower. ${ }^{22}$

Ketogenic diet as cancer treatment also shows convincing result to be used as an adjuvant. However, this might work in a range of cancers. There is a term called the Warburg Effect, an alteration of metabolism from anaerob to aerobic glycolysis in order to increase glucose uptake followed by fementation of lactate from glucose. ${ }^{23}$ It is said that ketogenic diet targets the Warburg Effect in cancer, so that cancer cells will be lack of energy to stay, and meanwhile, normal cells will adapt to metabolize ketone bodies, whereas cancer cells cannot metabolize ketone bodies due to deficiencies of mitochondrial enzymes. Moreover, ketogenic diet targets to decrease circulating blood glucose in order to induce ketosis, and results in starvation in cancer cells. ${ }^{10}$ Similar result is also obtained by Zhou et al. (2007), ketogenic diet is proven to have anti-tumor and anti-angiogenic effects in brain tumors even in human. However, it should be noted that this ketogenic diet is administered in restricted amounts. By restricting the calories, lower circulating glucose levels was found, and it is believed that tumor growth is more likely to associate with circulating glucose levels rather than circulating ketone bodies levels. Furthermore, it is found more effective to increase circulating ketone bodies in restricted administration. ${ }^{24}$

High-fat diet also shows inhibition effect in cell proliferation. High-fat diet affects serum progesterone 
and a decrease in serum progesterone is found. The presence of progesterone will increase cell proliferation through activation of NF-KB signaling pathway. Tumor development induced by progesterone through Receptor Activator of NF-KB Ligand (RANKL) stimulation. Then, RANKL is extricated to extracellular space and binds with its receptors in stem cells. This active RANKL will activate NF-KB signaling, and results in cell proliferation. ${ }^{18}$

These selected studies mostly examined in inflammatory process, as in inflammation is the initiation of cancer. However, these studies used high-fat diet to induce the inflammation. As mentioned before that inflammatory process promotes apoptosis, therefore it was found that $\mathrm{Bcl}-2$ was decreased. ${ }^{11,13}$ In contrary, Masino and Ruskin (2013) reported that ketogenic diet can reduce inflammation. Metabolism of ketone leads to produce reactive oxygen species in smaller amount, and thus, inflammatory process will be diminished. High-fat content in the diet will increase fatty acid level in the body, as well as long-chain of polyunsaturated fatty acid, that will bind with peroxisome-proliferator-activated receptor. This activation leads to transcriptional changes that boost metabolism of lipid. Moreover, ketone metabolism in ketogenic diet is proven to increase adenosine, which is known to act as an anti-inflammatory. ${ }^{25,26}$ According to Forsythe et al. (2008), VLCKD (Very Low Carbohydrate Ketogenic Diet) administration results in significant reduction of serum inflammatory marker, such as Tumor Necrotic Factor (TNF)- $\alpha$, Interleukin (IL)-6, IL-8, Monocyte Chemoattractant Protein-1 (MCP-1), E-selectin, Intercellular Adhesion Molecule (ICAM), and Plasminogen Activator Inhibitor-1 (PAI-1), and even lower compare to administration of low-fat diet. ${ }^{27}$ Although inflammation is the initiation of cancer, not every inflammatory process can proceed to cancer. It requires several events to develop a cancer. ${ }^{28}$

This study has some limitation, because there has not been done much the study about ketogenic diet and cancer itself before. Therefore, further research about ketogenic diet and cancer itself is needed to be done. Most of all selected studies examined under inflammatory process. Even though cancer can be induced by chronic inflammation, not every inflammation will develop into cancer. Ratio of ketogenic diet content might affect the effectiveness as cancer adjuvant. Therefore, further studies can explore more about the ratio of ketogenic diet content might be useful.

\section{Conclusion}

From these all selected experimental studies that has been reviewed, ketogenic diet, which contain of high-fat diet will reduce Bcl-2 expression. As a cancer adjuvant, it could be useful by inducing apoptosis and inhibiting proliferation. Ketogenic diet may affect cancer in several mechanisms. It can also help to reduce inflammation. For further research, it is necessary to explore more about ketogenic diet and cancer itself, since it has not been done much. Furthermore, the ratio of the diet might be related and affect the effectiveness, but this needs further research as this was not assessed in this study.

\section{Conflict of Interest}

There is no conflict of interest to declare.

\begin{tabular}{ll}
\hline Abbreviations & \\
3'-UTR & : Three Prime Untranslated Region \\
BAX & : Bcl-2 Associated X protein \\
Bcl-2 & : B-cell lymphoma-2 \\
Bcl-xL & : B-cell lymphoma-extra large \\
ICAM & : Intercellular Adhesion Molecule \\
IL-6 & : Interleukin-6 \\
IL-8 & : Interleukin-8 \\
MCP-1 & : Monocyte Chemoattractant Protein-1 \\
Mdm-2 & : Murine Double Minute-2 \\
miR-429 & $:$ micro RNA-429 \\
NF-KB & $:$ Nuclear Factor KB \\
PAI-1 & $:$ Plasminogen Activator Inhibitor-1 \\
PI3K & $:$ Phosphatidylinositol 3-Kinase \\
RANKL & $:$ Receptor Activator of NF-kB ligand \\
TNF- $\alpha$ & $:$ Tumor Necrotic Factor- $\alpha$ \\
VLCKD & $:$ Very Low Carbohydrate Ketogenic \\
Diet &
\end{tabular}

\section{References}

1. Shilpa J, Mohan V. Ketogenic diets: Boon or bane?. The Indian journal of medical research. 2018;148(3):251-253.

2. Kalra S, Singla R, Rosha R, Dhawan M, Khandelwal D, Kalra B. The Ketogenic Diet. US Endocrinology. 2018;14(2):62-64.

3. WHO. Cancer [Internet]. 2019 [cited 2019 May 27]; Available from: https://www.who.int/news-room/fact-sheets/detail/cancer

4. WHO. Early detection of cancer [Internet]. 2019 [cited 2019 May 27]; Available from: https://www.who.int/cancer/detection/en/

5. National Cancer Institute. Risk Factors for Cancer [Internet]. 2015 [cited 2019 Jun 7];Available from: https:/www.cancer.gov/aboutcancer/causes-prevention/risk

6. Kamińska M, Ciszewski T, Łopacka-Szatan K, Miotła P, Starosławsk E. Breast cancer risk factors. 2015;14(3):196-202.

7. Irmawati A, Jasmin N, Sidarningsih. The effect of moderate exercise on the elevation of $\mathrm{Bax} / \mathrm{Bcl}-2$ ratio in oral squamous epithelial cells induced by benzopyrene. Veterinary World. 2018;11(2):177-180.

8. National Cancer Institute. NCI Dictionary of Cancer Terms [Internet]. 2019 [cited 2019 May 27];Available from: https:/www.cancer.gov/ publications/dictionaries/cancer-terms/def/bcl2

9. Campbell KJ, Tait SWG. Targeting BCL-2 regulated apoptosis in cancer. Open Biology. 2018;8(5):1-11.

10. Weber DD, Aminazdeh-Gohari S, Kofler B. Ketogenic diet in cancer therapy. AGING. 2018;10(2):164-165.

11. Sakr HF, Abbas AM, Khalil K, Shata AM. Modulatory effect of concomitant administration of sitagliptin and vitamin $\mathrm{E}$ on inflammatory biomarkers in rats fed with high fat diet: role of adiponectin. Journal of Physiology and Pharmacology. 2019;70(6):955-967.

12. Liu Y, Zhang Y, Hu M, LiY, Cao X. Carnosic acid alleviates brain injury through NF-אB-regulated inflammation and Caspase-3-associated apoptosis in high fat-induced mouse models. Molecular Medicine Reports. 2019;20(1):495-504.

13. Sahraoui A, Dewachter C, Medina GD, Naeije R, Bouguerra SA, Dewachter L. Myocardial Structural and Biological Anomalies Induced by High Fat Diet in Psammomys obesus Gerbils. PLoS One. 2016;11(2):1-16.

14. Hill AA, Anderson-Baucum EK, Kennedy AJ, Webb CD, Yull FE, Hasty AH. Activation of NF- $\kappa$ B drives the enhanced survival of adipose tissue macrophages in an obesogenic environment. Molecular Metabolism. 2015;4(10):665-677.

15. Zhang T, Tian F, Wang J, Jing J, Zhou SS, Chen YD. AtherosclerosisAssociated Endothelial Cell Apoptosis by MiR-429-Mediated Down Regulation of Bcl-2. Cellular Physiology and Biochemistry. 2015;37(4):1421-1430.

16. Gong WH, Zheng WX, Wang J, Chen SH, Pang B, Hu XM, et al. Coexistence of hyperlipidemia and acute cerebral ischemia/ reperfusion induces severe liver damage in a rat model. World Journal of Gastroenterology. 2012;18(35):4934-4943.

17. Aguiar e Silva MA, Vechetti-Junior IJ, Ferreira do Nascimento A, Furtado KS, Azevedo L, Ribeiro DA, et al. Effects of swim training on liver carcinogenesis in male Wistar rats fed a low-fat or high-fat diet. Applied Physiology, Nutrition, and Metabolism. 2012;37(6):11011109. 
18. de Oliveira Andrade F, Fontelles CC, Rosim MP, de Oliveira TF, de Melo Loureiro AP, Mancini-Filho J, et al. Exposure to lard-based high-fat diet during fetal and lactation periods modifies breast cancer susceptibility in adulthood in rats. The Journal of nutritional biochemistry. 2014;25(6):613-622.

19. Dogan S, Hu X, Zhang Y, Maihle NJ, Grande JP, Cleary MP. Effects of high-fat diet and/or body weight on mammary tumor leptin and apoptosis signaling pathways in MMTV-TGF- $\alpha$ mice. Breast Cancer Research. 2007;9(6):1-15

20. Wu Y, Zhang Z, Liao X, Qi L, Liu Y, Wang Z. Effect of high-fat diet-induced obesity on the Akt/FoxO/Smad signaling pathway and the follicular development of the mouse ovary. Molecular Medicine Reports. 2016;38(4):3894-3900.

21. Gottlieb TM, Leal JFM, Seger R, Taya Y, Oren M. Cross-talk between Akt, p53 and Mdm2: possible implications for the regulation of apoptosis. Oncogene. 2002;21(8):1299-1303.

22. Harahap H, Irfannuddin I, Murti K. Pengaruh Diet Ketogenik Terhadap Ekspresi Ki-67, Caspase-3, Dan MDA pada Jaringan Hati, Jambi Medical Journal. 2018;6(2):185-194.

23. Liberti MV, Locasale JW. The Warburg Effect: How Does it Benefit Cancer Cells?. Trends Biochem Sci. 2016;41(3):211-218.
24. Zhou W, Mukherjee P, Kiebish MA, Markis WT, Mantis JG, Seyfried $\mathrm{TN}$. The calorically restricted ketogenic diet, an effective alternative therapy for malignant brain cancer. Nutrition \& Metabolism. 2007:4:1-15

25. Masino SA, Ruskin DN. Ketogenic Diets and Pain. Journal of Child Neurology. 2013;28(8):993-1001.

26. Masino SA, Li T, Theofilas P, Sandau US, Ruskin DN, Fredholm $\mathrm{BB}$, et al. A ketogenic diet suppresses seizures in mice through adenosine A1 receptors. The Journal of Clinical Investigation. 2011;121(7):2679-2683.

27. Forsythe CE, Phinney SD, Fernandez ML, Quann EE, Wood RJ, Bibus DM, et al. Comparison of Low Fat and Low Carbohydrate Diets on Circulating Fatty Acid Composition and Markers of Inflammation. Lipids. 2008;43(1):65-77.

28. National Center on Health, Physical Activity and Disability (NCHPAD). Cancer and Exercise [Internet]. 2020 [cited 20 December 2020];Available from: https://www.nchpad.org/163/1258/ Cancer and Exercise 